\title{
Trial and Error: Between Criticism and Essayism (Karol Irzykowski)
}

"Since my thoughts are really precious to me and I do not want them to be attacked by missiles of the most primitive kind, I do not send them out into the world without armouring them first, and even equip them with weapons of offence."1 This quote, taken from the final pages of Karol Irzykowski's celebrated novel Patuba (The Hag, 1903), sheds light on some essential features of Irzykowski's approach to writing, particularly within the genre of the essay. To begin with, the assertive and belligerent tone of the final part of The Hag (characteristically titled "Szaniec Paluby," i.e., "The Rampart of The Hag") prefigures the military metaphors that abound in Irzykowski's large body of literary criticism and essays from the 1920s and 1930s. Titles like Walka o treść (The Struggle over Content,1929) and Lizejszy kaliber (Lighter Caliber, 1938) suggest that Irzykowski conceived of literary communication (and human interaction in general) in terms of conflicts, duels, and polemics rather than as a constructive dialogue between benevolent partners. The pugnacious tone of some of these books and essays should not be taken to mean, however, that Irzykowski was merely a rabble-rouser and provocateur, with little to offer by way of new values and ideas. More a method than a goal in itself, Irzykowski's constant polemic with his opponents' opinions was predominantly a tool for delineating and developing the author's own propositions - a strategy that has aptly been called "polemical digressiveness" (Nycz) or "radicalized dialogism" (Panek). ${ }^{2}$

As a genre that foregrounds the process of thinking, the essay is known for its questioning and tentative character. More often than not, Irzykowski's intellectual "trials" take the form of criticism directed against existing ideas and values. In addition to Irzykowski's characteristically militant tone, the above-quoted statement from The Hag exhibits the critical-intellectual mode that would become a dominant feature of Irzykowski's essays in the first three decades of the twentieth century. Significantly, while The Hag - Irzykowski's prose debut - served primarily as a metafictional attack on the artistic practices of the Young Poland period, Irzykowski's subsequent work would widen its polemical focus from fiction writing to literary and cultural criticism in the broadest sense.

Irzykowski's conception of his critical output is inextricably linked to his profound anthropocentrism as a writer. Unwilling to accept any values or absolutes originating outside man's experience or that threaten his individuality, Irzykowski considered the realm of creativity to be the most important - if not the only - site of negotiation for values and ideas. "Cultural work," he stated in the prewar article "Świat pracy a świat emocji”" (The Realm of Work and the Realm of Emotions, 1907), 
Undeniably, in our days one of these hidden ossifications, or - as [Stanisław] Brzozowski calls them - these carrions that decompose under festoons of flowers, is artistic ossification. Everyone senses this, yet so far the struggle with this ossification has been, by and large, merely illusory, a new means for conserving the old error. ${ }^{3}$

More often than not, Irzykowski's omnipresent authorial voice refrains from discussing art in purely aesthetic terms (e.g., "good" versus "bad" art). Instead, his approach is to "test" the cognitive and axiological potential of the works of art of a given epoch. This partly explains why so many of his critical writings abound in terms like "false," "error," and "mistake" - terms usually applied to artistic ideas and values that have been subjected to "ossification," "petrification," and even "fossilization" and are thus ripe for overturning. Irzykowski's pursuit of originality and inventiveness is another key element in his writings of the interwar period. More than any other literary critic of his day, Irzykowski was allergic to - and implacable towards - writers and artists who dared to repeat, let alone plagiarize, established ideas and opinions. Irzykowski's critical method relies on a two-step process of egocentric analysis or "decomposition," as he liked to call it, followed by "re-composition," where the critic proposes alternative artistic solutions. As such, criticism (understood as the testing of the existing order and its hierarchies) and essayism ("trying" something yet unknown) appear to be two sides of the same coin.

Irzykowski's texts abound in terms such as "critique" and "criticism," yet scarcely make explicit references to the essay as a literary form. As early as The Hag, however, his work displays a certain predilection for terms that express tentativeness, most notably "próba" (trial, attempt). The term "essay" itself makes a rare appearances in the introduction to his volume of film theory Dziesiata Muza. Zagadnienia estetyczne kina (The Tenth Muse: Esthetic Issues of Cinema, 1924) and in Beniaminek. Rzecz o Boyu-Żeleńskim (Little Benjamin: On Boy-Żeleński, 1933).

As the above-quoted passage from "The Realm of Work and the Realm of Emotions" indicates, when Irzykowski was beginning his critical writing, he felt a strong affinity for the work and ideas of his contemporary, the critic and philosopher Stanisław Brzozowski (1878-1911). Arriving on the Polish literary scene at the turn of the century, both Irzykowski and Brzozowski took issue with the Young Poland movement and combined forces to intellectualize Polish social and cultural life. Among the "ossifications" that Irzykowski criticized in the aforementioned article (written, in part, to defend Brzozowski's own views on the matter) was the "convenient dualism that makes easier the resolution (the naming!) of difficult aesthetic problems: like content/form, intellectual and moral questions/aesthetic questions, the realm of ideas/the realm of emotions, social qualities/artistic qualities." 4 Well aware of the inadequacy of so-called word-postulates that is, the lofty, transcendental concepts such as "truth," "love," and "beauty" that tend to govern human behaviour - Irzykowski questioned artificial categories and simplifying labels that distorted "real life" or "the truth about life." While the perceived dualism between content and form is at the polemical heart of Irzykowski's interwar volume The 
Struggle over Content, other dichotomies figure prominently in his earlier, elaborate critique of the artistic practices of Young Poland titled Czyn i stowo. Glossy sceptyka (Deed and Word: Comments of a Sceptic, 1913).

One issue of particular importance to Irzykowski as a critic was the abrupt shift from "decadentism" ("art for art's sake") to "heroism" ("art for society's sake") that some of his contemporaries made in the aftermath of the 1905 Revolution in Russia. For Irzykowski, as he wrote in the 1907 article "Dwie rewolucje" (Two Revolutions), this socio-ethical turn was an all too easy retreat into outdated cultural reflexes and showed a superficial understanding of the tenets of modernism in general, and of decadentism in particular. Rather than perpetuate such "false" dichotomies, Irzykowski envisioned a reconciliation of the two currents - decadentism and heroism - in what he termed "intellectual activism"; here, a critical awareness of cultural decline ("decadentism") would go hand in hand with a commitment to "revolutionary" thinking ("heroism"). In a similar vein, Irzykowski took issue with the widespread conception of history as a circular movement, or as a pendulum swinging between opposite poles (reflected in the various "neo" labels then in vogue). Instead, most notably in his article "W kształt linii spiralnej" (In the Form of a Spiral Line, 1913), he proposed that historical "progress" moved in a spiral.

While Irzykowski's prewar criticism revolved around the Young Poland current, his later writings turned to the generation that arrived on the Polish literary scene after the First World War, a generation that Irzykowski ironically nicknamed "Youngest Poland." The specifically Polish contexts in which these polemics arose make Irzykowski's critical output less accessible to a contemporary - and even more so a foreign - readership, and obscure some of its more general underpinnings. Nevertheless, these concrete (con)textual references are both the basis and the strength of his authorial approach, which focused on particulars and topical examples rather than on building an all-encompassing, and inevitably generalizing, conceptual framework. Along with the critical-essayistic mode of his writings, it helps explain why his intellectual position has been categorized as "pragmatism," or even "irrational rationalism" (i.e., rejecting systemic and systematic thinking in favour of tentative reflection). ${ }^{5}$ It also allows one to consider Irzykowski in the same light as Georges Sorel, Friedrich Nietzsche, Georg Simmel, Henri Bergson, and other modernist essayists known for their deep suspicion of systematic reasoning, however much they diverged on numerous ideological and artistic points.

By making aesthetic criticism central to his intellectual activities and foregrounding the "refreshing impact of original elements of mutation" in his evaluation of art, Irzykowski anticipated a number of important developments in twentieth-century critical theory.

Victor Shklovsky introduced the concept of "ostranenie" (usually translated as "defamiliarization") in his famous essay "Art as Device" from 1917. Starting from the idea that repeatedly performed acts lead to a form of habituation (especially in the realm of perception), Shklovsky claims that art and its various devices and techniques allow us to counter this process of automatization. By making the artistic form "strange" and "difficult" (in comparison to existing and established forms of expression), poetic language is capable of deautomatizing the reader's perception and shifts the focus of attention from the knowledge of an object to its activated and renewed perception. 
Irzykowski's ideas about "ossification" and "refreshing mutation" were echoed, to some extent, by the Russian Formalist School, in particular by Victor Shklovsky, who analysed the dynamic between "automatization" and "defamiliarization." It would be a mistake, however, to reduce Irzykowski's legacy to his aesthetic criticism, groundbreaking though it may be. His concern over the socially and psychologically conditioned mechanisms that hamper the "crystallization" and "fermentation" of new ideas and values (to use his own terms) is just one facet of his legacy. His anthropocentric convictions prompted fierce debates over contemporary discourses that reduced human beings to "automatons," mere pawns to be sacrificed for the future benefit of the collective. His convictions shine through in the celebrated 1918 essay "Filozofia koralowa a religia" (Coral Philosophy and Religion), in which he ironically minimizes the enormous loss of life in the First World War: "We are eternal because we are a society of corals after all, constantly growing one above another and branching off like trees in the ocean of being ... Death has become a trifle, the dead are nothing but the excrement of a huge body." A staunch opponent of war in the real world, the belligerent critic Irzykowski appears in these pages in one of his more pessimistic guises, as he indicts the misguided spirit of collectivism that would cause so much destruction in the decades to come.

\section{Kris Van Heuckelom \\ Catholic University of Leuven}

\section{NOTES}

1 Irzykowski, Patuba, 576. All translations from the Polish are mine.

2 Nycz, "Wynajdywanie porządku," 156-7; Panek, Krytyk w przestrzeniach literatury i filozofii, 76.

3 Irzykowski, Wybór, 66.

4 Ibid., 68.

5 See Burek, "Cztery dyskusje Karola Irzykowskiego," 129-82.

6 See Nycz, "Wynajdowanie," 165-82; and Sienkiewicz, "Zamiast wstępu," 9-28.

7 Irzykowski, "Filozofia koralowa a religia," 101.

\section{WORKS CITED}

Burek, Tomasz. “Cztery dyskusje Karola Irzykowskiego. Prolegomena.” In Problemy literatury polskiej lat 1890-1939, vol. 1. Edited by H. Kirchner and Z. Żabicki. 129-82. Wrocław: Ossolineum, 1972.

Irzykowski, Karol. "Filozofia koralowa a religia." In Alchemia ciała i inne szkice oraz aforyzmy. 98-105. Wrocław: Towarzystwo Przyjaciół Polonistyki Wrocławskiej, 1996.

- Paluba. Sny Marii Dunin. Kraków: Wydawnictwo Literackie, 1976.

- Wybór pism krytycznoliterackich. Wrocław: Ossolineum, 1975.

Nycz, Ryszard. "Wynajdywanie porządku. Karola Irzykowskiego koncepcje krytyki i literatury.” In Język modernizmu. Prologomena historycznoliterackie. 155-90. Wrocław: Wyd. Uniwersytetu Wrocławskiego, 2002.

Panek, Sylwia. Krytyk w przestrzeniach literatury i filozofii. Poznań: Poznańskie Studia Polonistyczne, 2006.

Sienkiewicz, Barbara. "Zamiast wstępu. Irzykowski - krytyk Lessinga.” In Między rewelacja a repetycją. Od Przybosia do Herberta. 9-28. Poznań: Poznańskie Studia Polonistyczne, 1999. 